\title{
MAGE-A3-expressing Adenovirus Type 5 Vaccine
}

National Cancer Institute

\section{Source}

National Cancer Institute. MAGE-A3-expressing Adenovirus Type 5 Vaccine. NCI

Thesaurus. Code C119614.

An oncolytic adenoviral vaccine composed of a replication-defective, E1- and E3-deleted adenovirus serotype 5 (Ad5) with a transgene encoding the human melanoma antigen A3 (MAGE-A3), with potential antineoplastic activity. Upon administration, MAGE-A3expressing adenovirus type 5 vaccine selectively replicates in cancer cells and expresses MAGE-A3. This induces an immune response against tumor cells expressing the MAGEA3 antigen, which leads to tumor cell death. The tumor-associated antigen MAGE-A3 is overexpressed by a variety of cancer cell types. 